\title{
2. Comitative placenames in central NSW $^{1}$
}

\author{
David Nash \\ The Australian National University and Australian Institute of \\ Aboriginal and Torres Strait Islander Studies
}

\section{Introduction}

Jerilderie, Narrandera, Cootamundra, Gilgandra are placenames familiar beyond their districts in inland New South Wales (NSW), and the casual observer can notice dozens of placenames with similar endings -dra,-drie,-dgery (and other English spellings), all taken (correctly) to be of Indigenous origin. The places with these names are all in inland NSW, and not in adjacent Victoria (or elsewhere in Australia).

The common ending of these placenames reflect a particular ending in Wiradjuri, a widespread Indigenous language of inland NSW. Indeed the ending is also present in the name of the language, and has had dozens of variant spellings, notably Wiradhuri, and Waradgery (as in the commemorative names Waradgery County and Waradgery Shire centred on Hay). The ending (or suffix) involved indicates a meaning which in English is conveyed by a separate word such as 'with', 'having', 'accompanied by', and so on. The term Comitative or Proprietive has been used to designate a suffix with such meanings; here I use Comitative to denote the suffix. The modern Wiradjuri dictionary lists the suffix thus:

-dhuray having, often used in place names applied to the name of an animal or vegetable, as in the following: Cootamundra (gudhamang-dhuray = having tortoise), Narrandera (ngarrang-dhuray, having frilled-lizard) Jerildery (dyiril-dhuray, having reeds) (R)² (Grant and Rudder 2010: 351)

This study looks into the etymology of placenames bearing the -dhuray suffix and shows that the evidence of these placenames can throw light on linguistic matters (such as on variation in morphology), on linguistic geography, and potentially on some aspects of culture.

1 This study overlaps with my presentation on the Wiradjuri Comitative suffix to the 11th Australian Languages Workshop, hosted by the University of Queensland at its Moreton Bay Research Station, Stradbroke Island, on 9-11 March 2012, and to the Parkes Wiradjuri Language Group on 13 March 2012. I am grateful to the participants, and subsequently to Ray Wood, for helpful comments. An earlier version of the data was included in Nash (1974), and Donaldson's $(1984,1985)$ work on related topics has provided guidance.

2 (R) is a reference to the source Richards (1902-03). 


\section{Method}

This study concentrates on the most securely documented instances of Comitative placenames: ones with a convincing combination of supporting information. I take as convincing the combination of two kinds of information from old sources (usually a source dating from the 19th century ${ }^{3}$ when the Wiradjuri language was still widely known): (a) an attribution of meaning to the particular placename bearing the Comitative suffix, together with (b) a corroboration in the Wiradjuri lexicon of the implied stem. Thus we are considering the more securely documented placenames with an etymology based on older records ('testimony') and wordlist data. For these we can have 'greatest certainty about the meaning of a placename' (Koch 2009: 147-148).

The investigation began when I combed the historical sources on Wiradjuri, and on other sources which include placename origins for the general area including Wiradjuri country. I compiled a list of those placenames apparently bearing the Wiradjuri Comitative suffix (ones terminating in -dra,-drie,-dgery etc) and concentrated on those with supporting etymological information.

As a check whether I had overlooked relevant placenames, I used the Geographical Names Register (GNR) of NSW (Geographical Names Board 2011). All names with location west of Longitude $150^{\circ} \mathrm{E}$ were extracted from the GNR, as the $150^{\circ} \mathrm{E}$ meridian falls conveniently to the east of Wiradjuri country and excludes most of the NSW placenames on and east of the Great Dividing Range (which form the majority). This subset of NSW placenames was then sorted from the end of the word, thereby grouping spellings ending such as dra, dry, drie, dgery, gerie, and some in dara. For only a handful of the extracted placenames does the GNR provide any 'Meaning' information (and what does occur usually repeats information I had already found in an old source).

These potentially relevant placenames and the etymological information (where available) were combined into a spreadsheet along with attributes of location and feature type. ${ }^{4}$ Along with the coordinates these placenames were transferred (via CSV format and GPSBabel+ software) to a KML file, and then displayed with software such as Google Maps, Google Earth, and QGIS.

3 The majority of the sources are lists published in the early 1900s in the journal Science of Man (SM). These lists are usually traceable to manuscript lists reproduced in Royal Anthropological Society of Australia (2004), comprising manuscript questionnaires on placenames returned in about 1899 from local Police and other officials.

4 The placenames in the spreadsheet can also be grouped into 'toponymic sets': placenames which involve the same base name (in the same spelling) in the one locality. Typically the places in such a set are differentiatied by feature type, and/or by various derivations of the base name (such as Tenandra Creek, Tenandra Hill, Tenandra Plain, Tenandra Knob). In this study, the toponymic sets were simplified by excluding names of the built environment, and prefering those of natural features and of intermediate types such as names of trignometrical stations (usually on a hill or mountain summit) or localities or cadastral divisions (parishes and counties). 


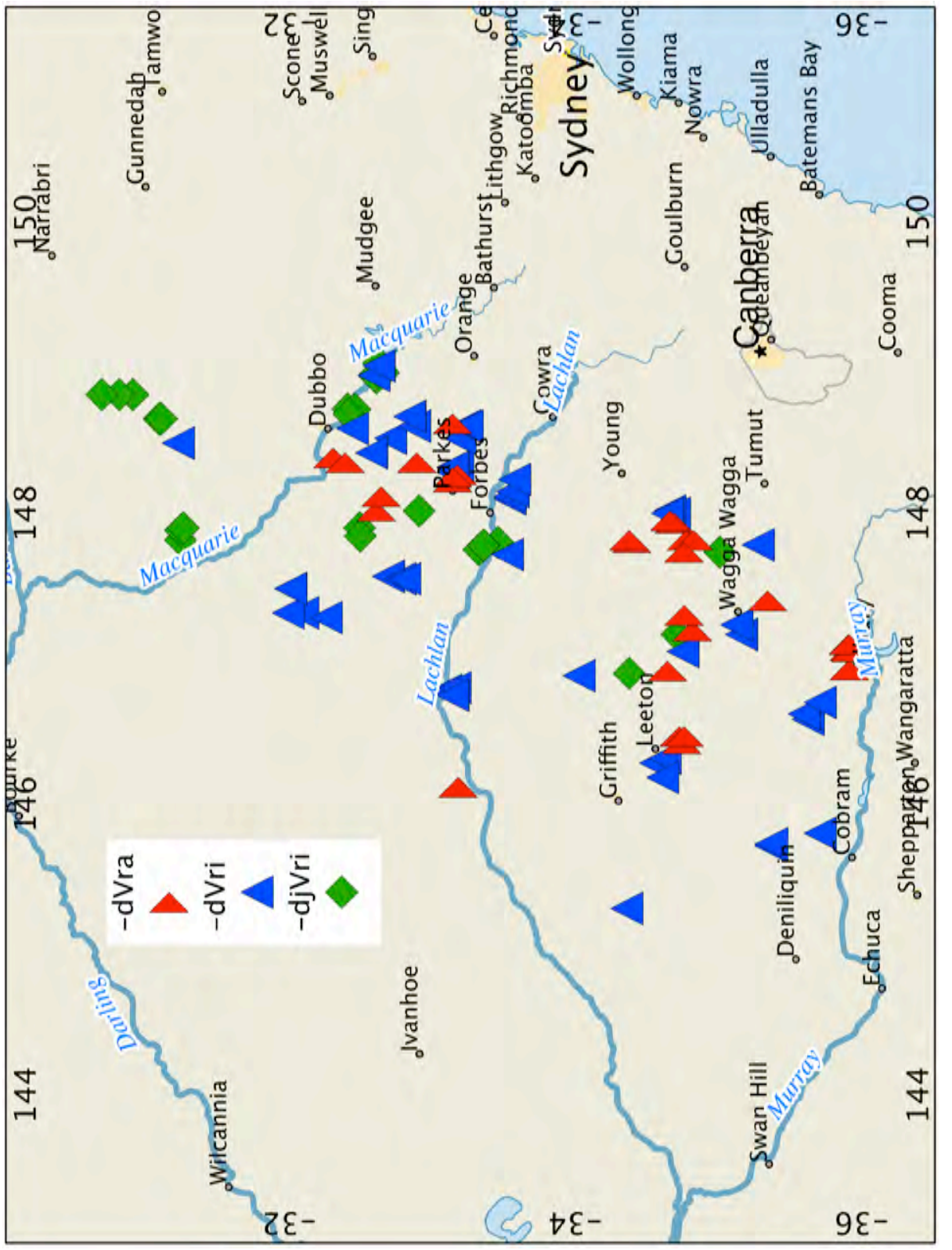

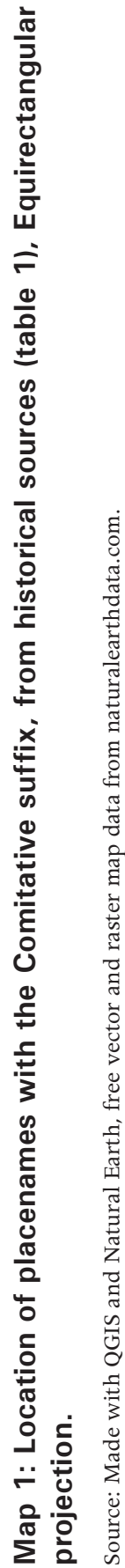




\section{Wiradjuri Comitative placenames}

As can be seen in map 1, the placenames of this study form a north-south band across central NSW. The form of the ending falls into three main types, as indicated by the location symbol used on the map:

1. -dVra dera, dra Narrandera, Gilgandra, ...

2. -dVri dry, drie, darie, thery Jerilderie, Mulyandry, ...

3. -djVri dgery, gerie, gery, jerry Eumungerie, Coradgery, ...

The placenames shown in map 1 are listed in table 1 along with information on the etymology. The first four columns provide the coordinates (in decimal degrees), the placename, and its feature type. All this information has been copied from the GNR where possible, however a few extra placenames are included from other sources. The 'source' column in table 1 is where the placename is associated with a meaning in old (usually 19th century) records. The 'stem' and 'gloss' column provides the stem and its meaning (usually in Grant and Rudder's spelling or sometimes a similar spelling using cover symbols such as $\mathrm{R}$ for an indeterminate rhotic, or $\mathrm{D}$ for an indeterminate non-peripheral stop consonant).

Note that the first vowel of the Comitative suffix is the high vowel /u/, and so placenames ending like dara are unlikely candidates to involve the Comitative suffix. This fits with the lack of etymological information for any of the potential candidates (such as Wattamondara). Also, no placenames happen to be included whose spelling terminates like djVra, again because for none of the candidates (such as Cookamidgera) is there etymological information.

In table 2 are other placenames in the same general area which appear to involve the Comitative ending, with for each the Wiradjuri stem which appears best to match with the form of the placename. The placenames in Table 2, however, lack supporting testimony from older sources, and the association with the Wiradjuri stem is no more than a suggestion, one that may tested by further research. The placenames listed in Table 2 are shown on Map 2. 

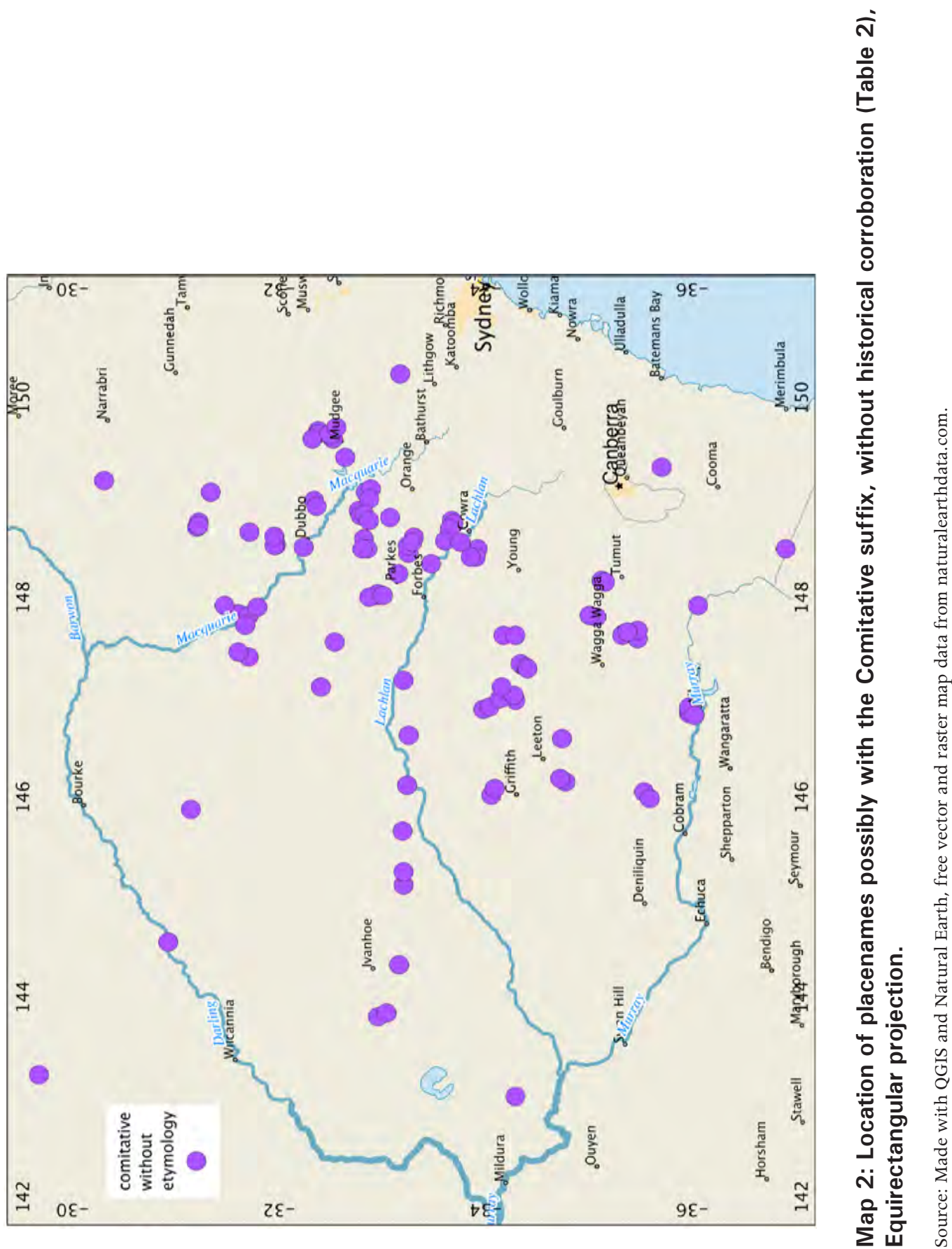


\section{Discussion}

Now that we have assembled the fairly secure information in Table 1 (and Map 1), and the more speculative but nonetheless valuable information in Table 2 (and Map 2), we can make some generalisations about the geographic distribution of the Wiradjuri Comitative placenames, and about the form of the suffix, and about its meaning and that of words bearing the suffix.

\subsection{Geographic distribution}

The placenames with a fairly secure Wiradjuri etymology (those in Table 1 and on Map 1) are, unsurprisingly, within the territory of Wiradjuri. This can be seen more clearly on Map 3, on which the language areas have been marked by Bowern (2011) in accordance with Tindale's (1970) map and similar sources.

The only names not within the Wiradjuri area indicated on Map 3 are a couple of names (Cajildry etc, and Gradgery) within Ngiyampaa country not far northwest of Wiradjuri country, and Teridgerie in the north. Interestingly the GNR tells us that Teridgerie Creek has Terembone Creek as an alternate name, and previous names 'Myall Creek; Urawilkie or Terembong Creek Teridg; Urawilkie Creek'; among these Terembone $\sim$ Terembong bears the Comitative suffix -buwan of the local language.

The names of Table 1 are noticeably absent from a strip along the east of Wiradjuri territory. The absence may be an accidental by-product of the adventitious ways in which Indigenous placenames made it onto colonial maps, or there may be some underlying causes discernible from the history of the early colonial period. One is that the colonists spreading westward from the Sydney region when first encountering Wiradjuri tended not to record Indigenous placenames, especially in the period before it was encouraged by the authorities (notably Macquarie and Mitchell). Another possibility is that Wiradjuri language is not involved in placenames in this eastern strip, and that the Wiradjuri spread eastward to occupy the strip when the original owning groups could not sustain their presence there (whether from disease, massacre, or forced relocation). Clearly this is a fraught topic, and I leave it for considered historical investigation. ${ }^{5}$

5 There is a parallel clustering of placenames ending in bri, such as Narrabri, Boggabri, Collarenebri, Kenebri, Mickibri. These derive from the Gamilaraay Yuwaalaraay suffix -Baraay (the reflex of *-baraay 'Comitative' pGY, Austin 1997: 33). Another parallel cluster is formed by placenames ending in bone (in English spelling), such as Quambone, Girilambone, Galargambone, Buttabone, exhibiting the Comitative suffix -buwan (as found in Ngiyaampa). These parallel placename endings are ripe for being analysed along similar lines. 


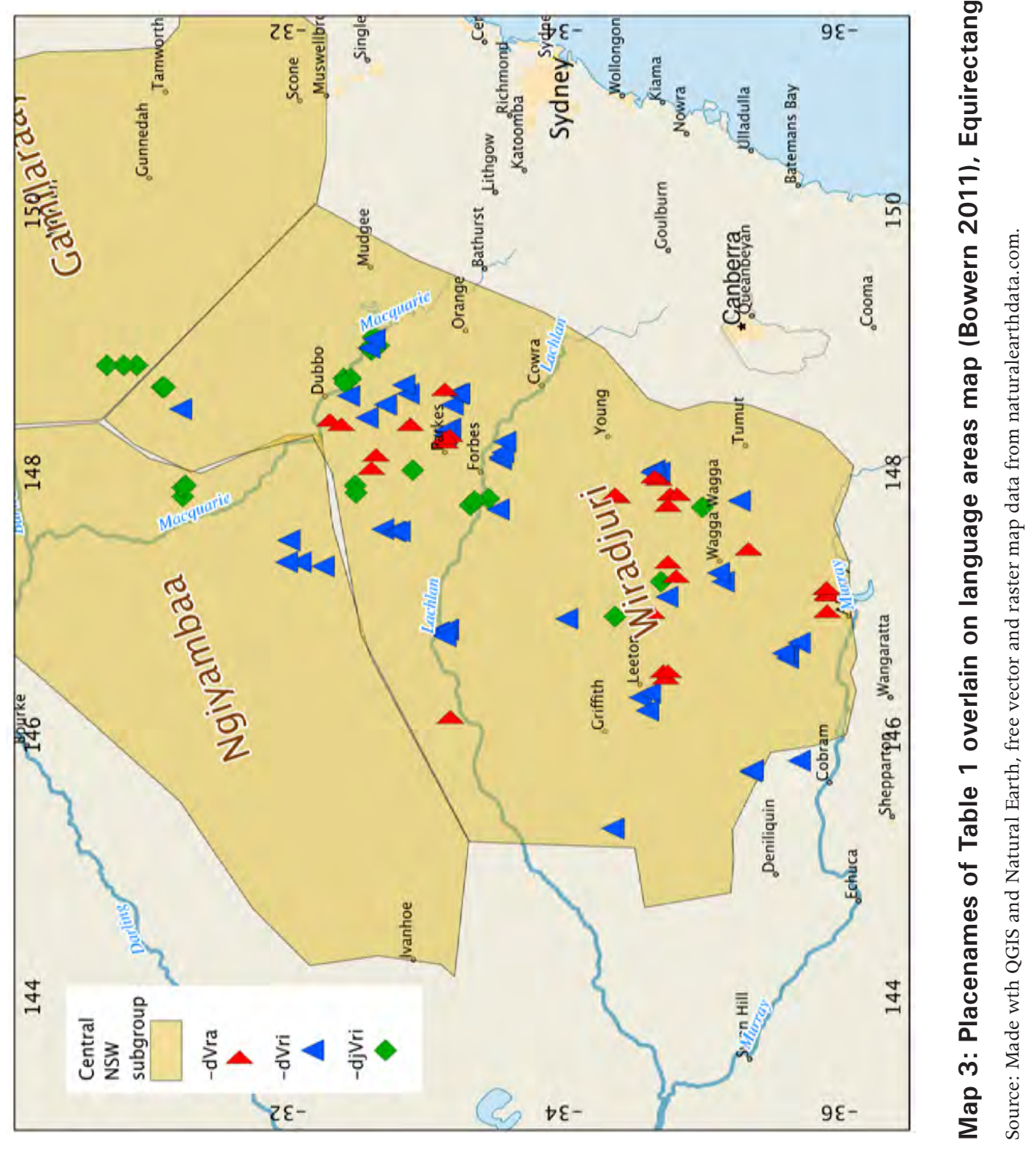


Turning to the placenames with speculative etymology involving the Wiradjuri Comitative, the names of Table 2, it is readily apparent that these (as on Map 2) are spread over a broader area. More so than on Maps 1 and 3, a number are located away from the focal cluster, and we can suspect these are not actually original Wiradjuri Comitative placenames. There are a couple of possible explanations for the existence of these outliers. One is that the placename shows a chance resemblance to a Wiradjuri word, but actually derives from its local language and does not exhibit the Wiradjuri Comitative ending. One possible example of this is Gindantherie Parish (about $35 \mathrm{~km}$ north of Lithgow). ${ }^{6}$

Another explanation for an apparent outlier is that it is a transplanted name, that is, one copied to another location in the colonial period or later. I have tried to minimise the effect of transplanted copy names in this study by the rule of thumb that names borne by natural or indigenous features are more likely to be original than names borne by an introduced feature (such as a street, house or small property). A copy name is noticeable when it is geographically out of place and spelled the same as a prior placename recorded within the focal cluster. A candidate example is Tarrabandra, a name applied to three separate Parishes; the ones in the far north-west and far south of the state may well have been copied, whereas the intermediate Parish is associated with a Rural Place (near Gundagai). We need to look for further historical evidence bearing on whether the outlier placenames were indeed transplanted.

Of course a transplanted name might be located well within traditional Wiradjuri country, and thus will not have an anomalous location. Similarly, some unanalysed placename may just show a chance resemblance to the Comitative ending. It has to be accepted that, given our incomplete record of the full Wiradjuri lexicon, and an absence of origin information for some placenames, there will be some placenames with unresolvable etymologies.

\subsection{The Wiradjuri Comitative suffix}

Grant and Rudder's Wiradjuri Dictionary (quoted in the Introduction) draws on the two previous published descriptions of Wiradjuri grammar. Both those descriptions date from the period 1838-40, at the Wellington Valley Mission, and were written independently of each other. Both arose from a missionary who was learning the language, namely J.W. Günther, and William Watson. (None of Watson's original analysis survives, and we know of it from his collaboration with the visiting philologist Horatio Hale.)

6 The name is borne also by a natural feature in the area, Gindantherie Pinnacle, for which the GNR records 'Named after the Parish in which it is situated.' This is an example counter to my rule of thumb: normally we would expect a Parish to be named after a natural feature rather than the reverse; however the natural feature name is of recent origin, and was 'Proposed 17th October 2006'. 
The 19th century grammars describe the Comitative suffix, and transcribed it as follows:

-durai 'Conjunctive case' (Günther 1892)

-dhurei, -dhurai (Watson in Hale 1846)

-durei 'with, in company with' (Hale 1846: 492)7

Consistent with this, Austin (1997: 39) reconstructed *-dhurraay 'comitative' for the Ngiyampaa-Wiradjuri subgroup of Proto Central NSW (pCNSW), drawing also on Donaldson's (1980) grammar of Ngiyampaa, Wiradjuri's closest neighbour, and the only other language whose Comitative suffix can have the same form as Wiradjuri's:

-DHuray is occasionally substituted for -buwan by some Trida speakers.

It does not appear to function differently from -buwan in any way, except that it is rarely used. (Donaldson 1980: 112).

In Ngiyampaa as in Wiradjuri, the suffix is the nominal Comitative, and "can often be conveniently glossed as 'having' or '(being) with"' (Donaldson 1980: 107). Note however there are next to no recorded placenames containing -DHuray in Ngiyampaa country (the exception is Cajildry etc on the Bogan River, mentioned in section 4.1 above). This would fit with Donaldson's (1980: 107) observation that the Ngiyampaa Comitative 'cannot mark forms whose reference is definite': placenames, like any proper name, are inherently definite.

The 19th century grammars of Wiradjuri described allomorphy in the nominal case endings of the Ergative and Locative, but mention no variation in the Comitative. ${ }^{8}$ That is, they do not tell us about variation that is now readily seen in the recorded Wiradjuri placenames. Consider the placenames of types $d V r a$ and $d V r i$ on Map 1; both types have much the same spread across the Wiradjuri area. Notice though that almost all the placenames of types $d V r a$ and $d V r i$ in Table 1 have a $n$ or $l$ immediately preceding the suffix (as in Narrandera, Jerilderie, and so on), whereas in the djVri type a palatal nasal (in pronunciation) or vowel immediately precedes the suffix (as in Eumungerie, Coradgery). There is only one vowel-final stem (dhulu 'spear') represented in the $d V r a$ and $d V r i$ types in Table 1.

7 Hale (1846: 483-484) differed from 'the orthography of the missionaries' in 'the omission of unnecessary letters, such as double consonants, and the $h$, which is employed by them to denote sometimes a nasal and sometimes a dental pronunciation of the consonant which it accompanies' and it is clear from his notes that he observed a dental articulation of the stop beginning this suffix. Hale implies that the $r$ is rolled or trilled (not the glide as in standard English). Hale also noted that the language basically had three vowels, and that e, o were variants of $i, u$ respectively. Hence the three analysts effectively agree on the form and meaning of the suffix.

8 Richards (1902-03) does comment on variation between $d h$ and $d j$ (and $y$ ) variants, as witness the title of his articles. 
The pattern can be described as an assimilation of the first consonant of the suffix, along these lines:

- $D H \rightarrow d$ immediately following $n$ or $l$

- $D H \rightarrow d j$ immediately following a palatal consonant $(y, n y)$

Note that some of the djVri type are derived from a stem ending in $y$, such as garay in Coradgery, and the $y$ drops out when the suffix is added. The general allomorphy pattern here accords with the pattern in Ngiyampaa, as detailed by Donaldson (1980).

\subsection{Final vowel variation and doublets}

There is variation evident also in the final vowel of the Comitative placenames. It seems that the -DHuray suffix can take two forms -DHura (the $d$ Vra type above) and -DHuri (the $d V r i$ and $d j$ Vri types above). This variation was not described in the 19th century grammars of Wiradjuri. I have not detected any pattern to the final vowel variation, apart from a partial geographical component: most $d V r a$ type placenames on Map 1 (represented by a red pushpin) are in the southern half of the distribution. There are only two in the northern half: Bulgandramine and Bindogandra, and both of these are somewhat unusual: Bulgandramine is the only placename where the stem+Comitative is compounded with another noun, barrgan+dura-mayin 'boomerang+Comitative-man'; ${ }^{9}$ and Bindogandra has an alternate of $d V r i$ type, Bindogandri. On the other hand, several of the $d V r a$ type placenames with speculative etymologies (Table 2) are in the north, such as Gilgandra, Gunnegaldra and Tenandra.

It can be noted here that there are a few Comitative placenames recorded by Günther near his Wellington Valley Mission, and they include the only known placenames which retained the final diphthong of the Comitative. These are presented in Table 3. Two of these, Dawindurai $\sim$ Douwingerie and Yurugaidyurai, are not listed in the GNR and there appears to be no other record of Yurugaidyurai. We might infer from this slim evidence that the pronunciation of the final ay diphthong changed to a simple vowel $a$ or $i$ during the 19th century.

Further on this variation, there are some pairs of similar placenames differing mainly in the final vowel of the ending (on the same stem), like the Bindogandra / Bindogandri pair already dicussed. Some of the pairs are quite distinct locations (such as Geraldra / Gereldery / Jerilderie, and Willandra / Willanthry Willandry), and some are a single location with variant forms of what we can presume is the one name (such as Cootamundra / Cootamundry and Gunnegaldrie / Gunnegaldra).

9 The final y of -DHuray also deletes before the suffix -Da in forming the instrumental suffix combination -DHurada; just as the final $y$ of a stem (such as garay mentioned above, or wiray 'no' in the name Wiradjuri) deletes before-DHuray. 
The others to be found in the tables are Ulandra / Ulundry Yullundry, and Timaldra / Timaldrie. (Another pair, not listed in the tables because of the lack of even a speculative etymology, is Mundawaddra / Mundawaddery in the Lockhart district.) The spread of these variant pairs counts against the north/ south pattern discerned on Map 1, and we are left without a satisfactory explanation for the final variation.

\subsection{Semantic pattern}

Consideration of semantics can assist the assessment of the fragmentary etymological information. For the placenames with relatively secure etymology, in Table 1, we can see that the stem meanings are concrete entities: flora and fauna terms, some artefacts, and some topographic terms. This semantic range corresponds fairly well with the range seen across the speculative etymologies indicated in Table 2.

\section{Conclusion}

The study shows that placename evidence can provide linguistic information to supplement grammatical description, and can demonstrate the affiliation with country of a particular Indigenous language. The study of this one suffix used to form placenames in one language (Wiradjuri) has shown a logical pattern in variations in the form of the suffix. The geographic distribution of the placenames is shown to match, and thereby be a further expression of, the extent of Wiradjuri country. 
Indigenous and Minority Placenames

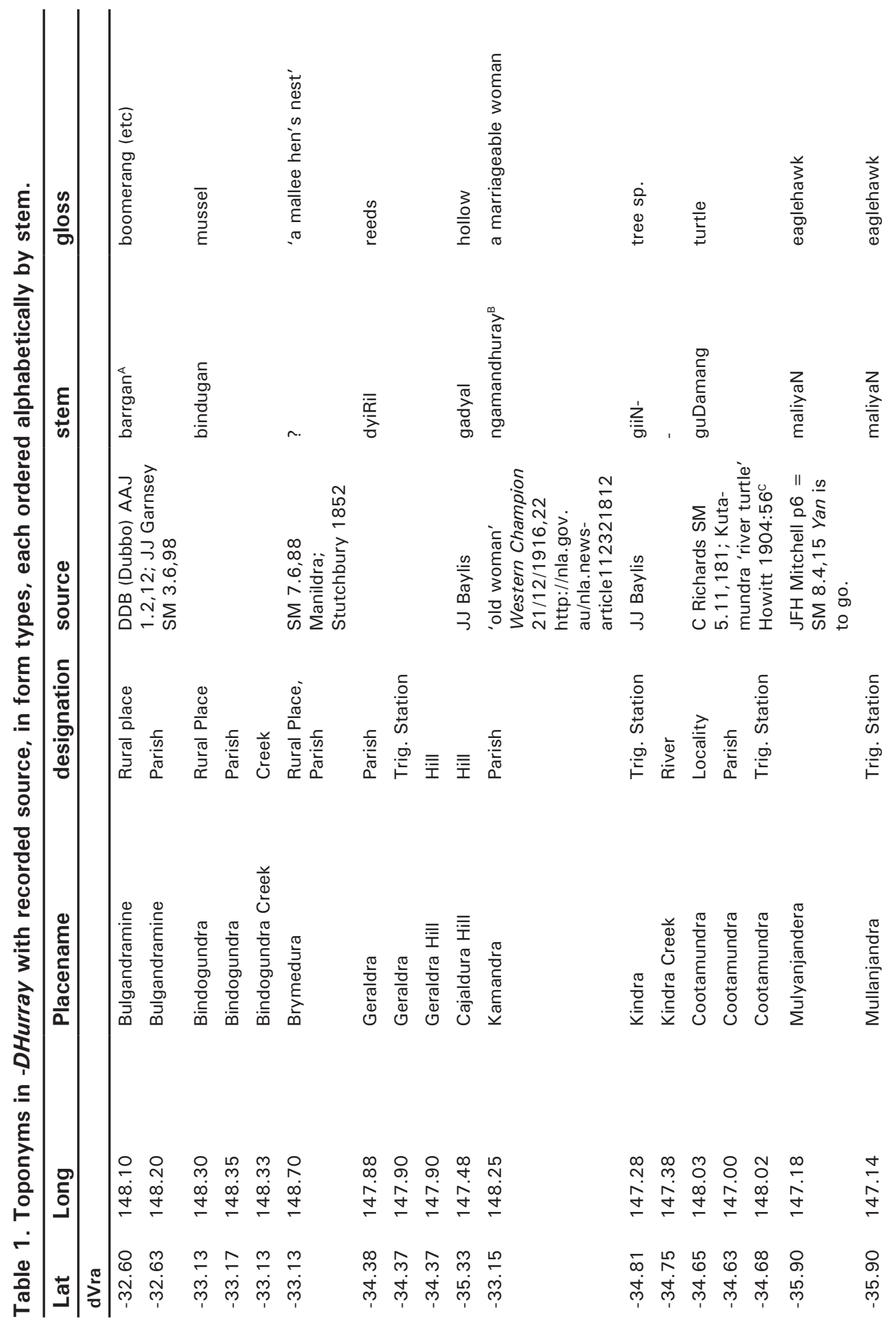


2. Comitative placenames in central NSW

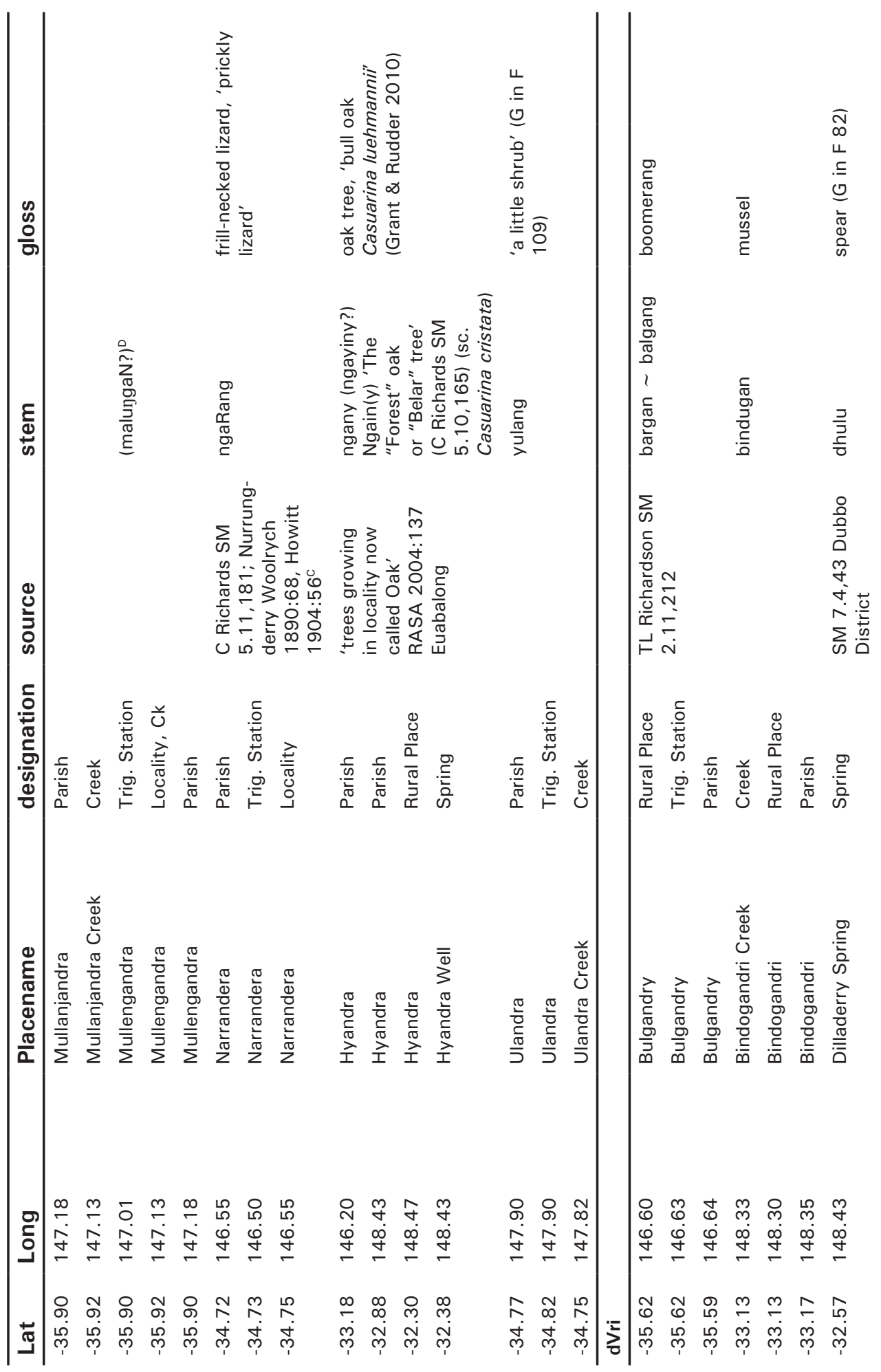


Indigenous and Minority Placenames

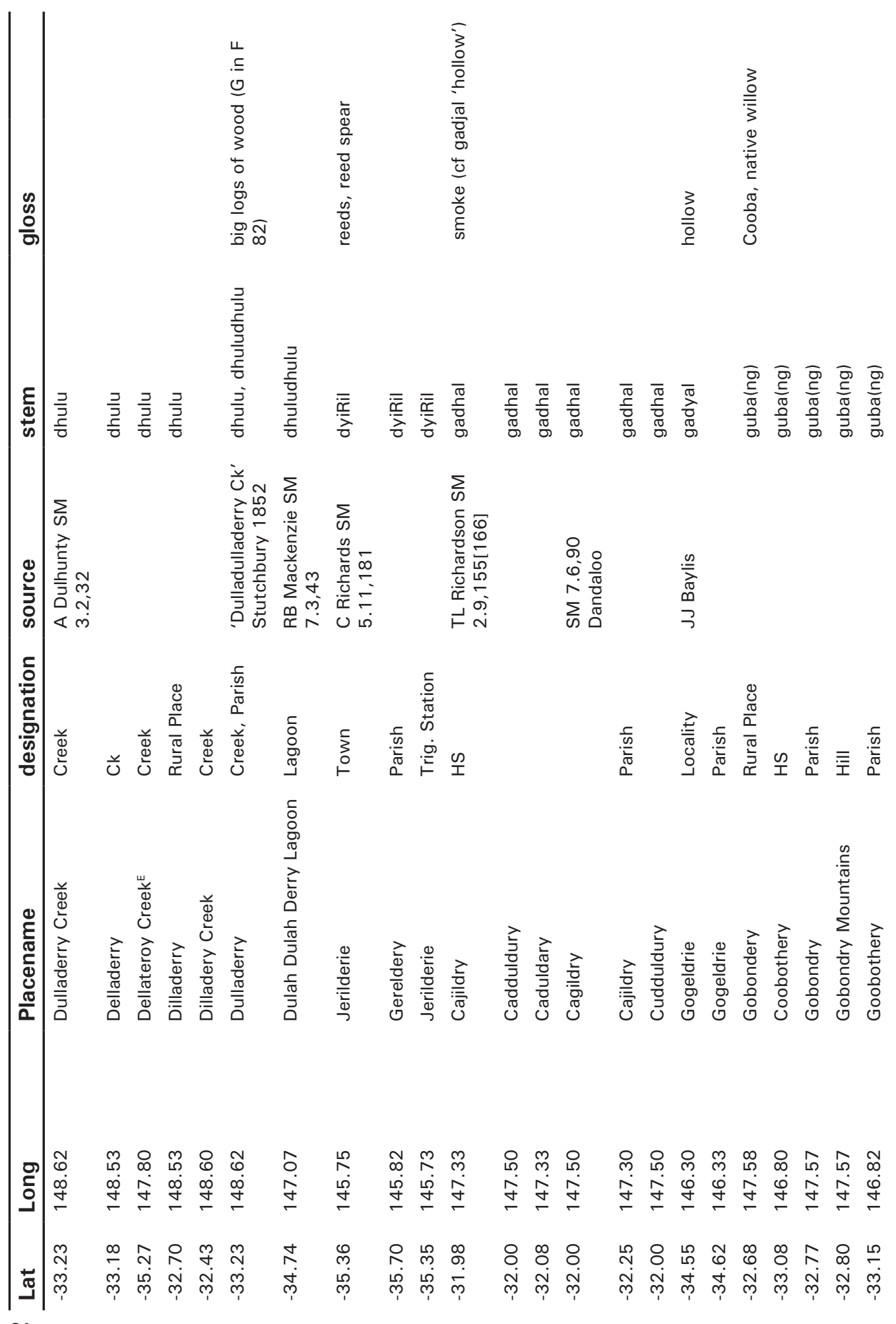




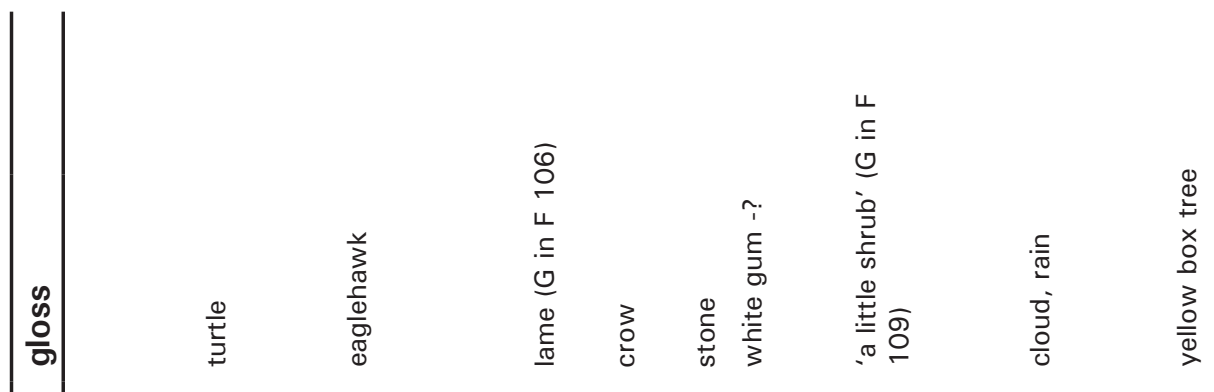

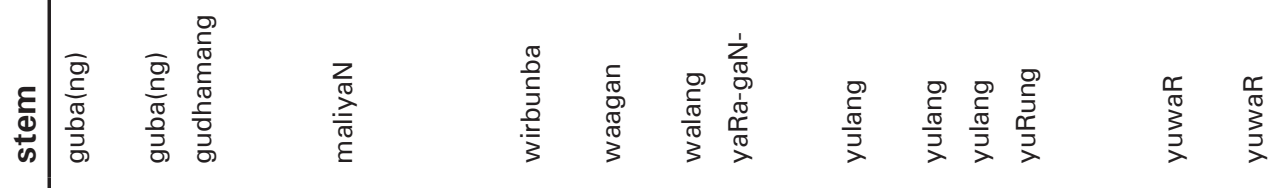

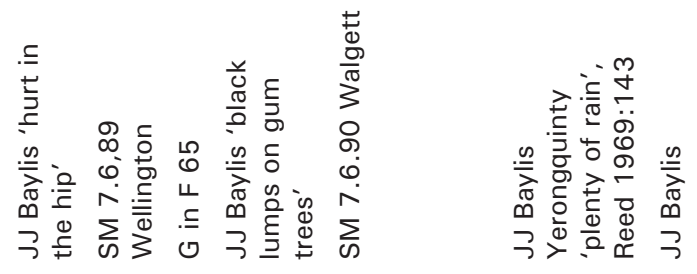

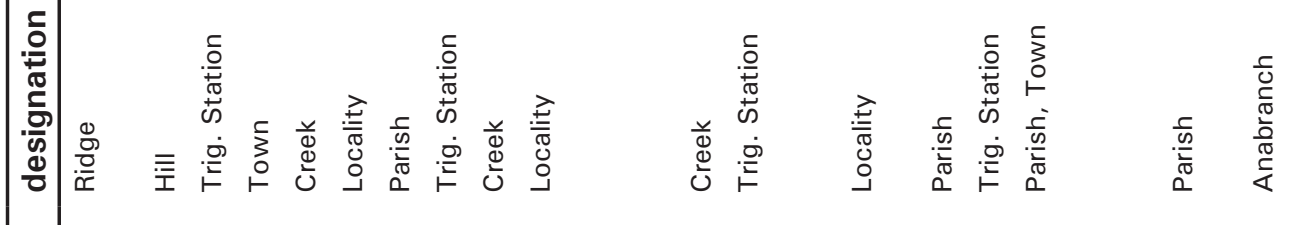

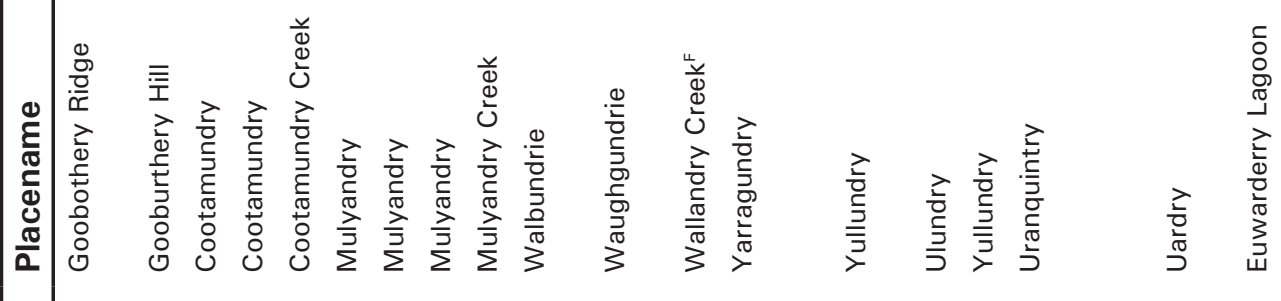

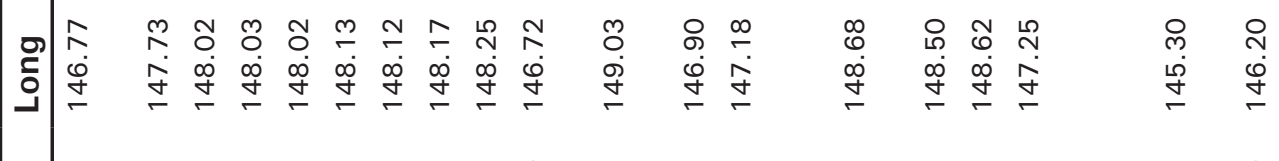

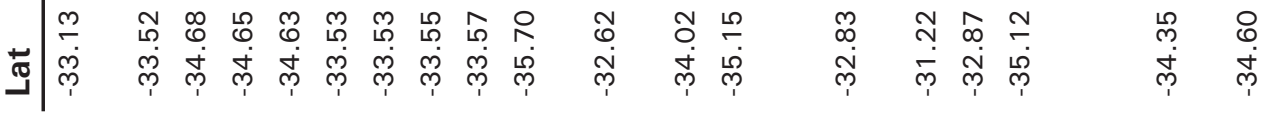


Indigenous and Minority Placenames

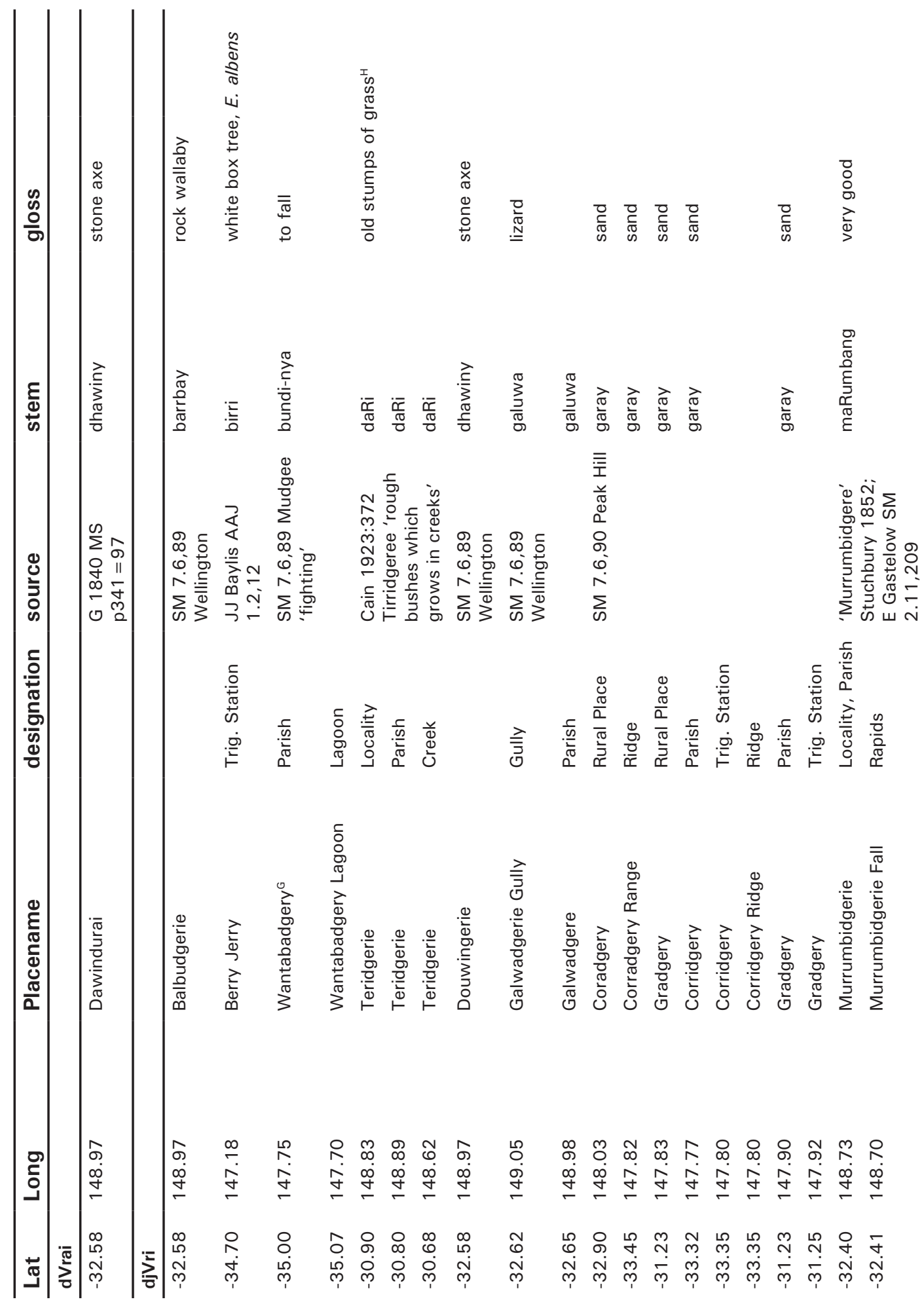


2. Comitative placenames in central NSW

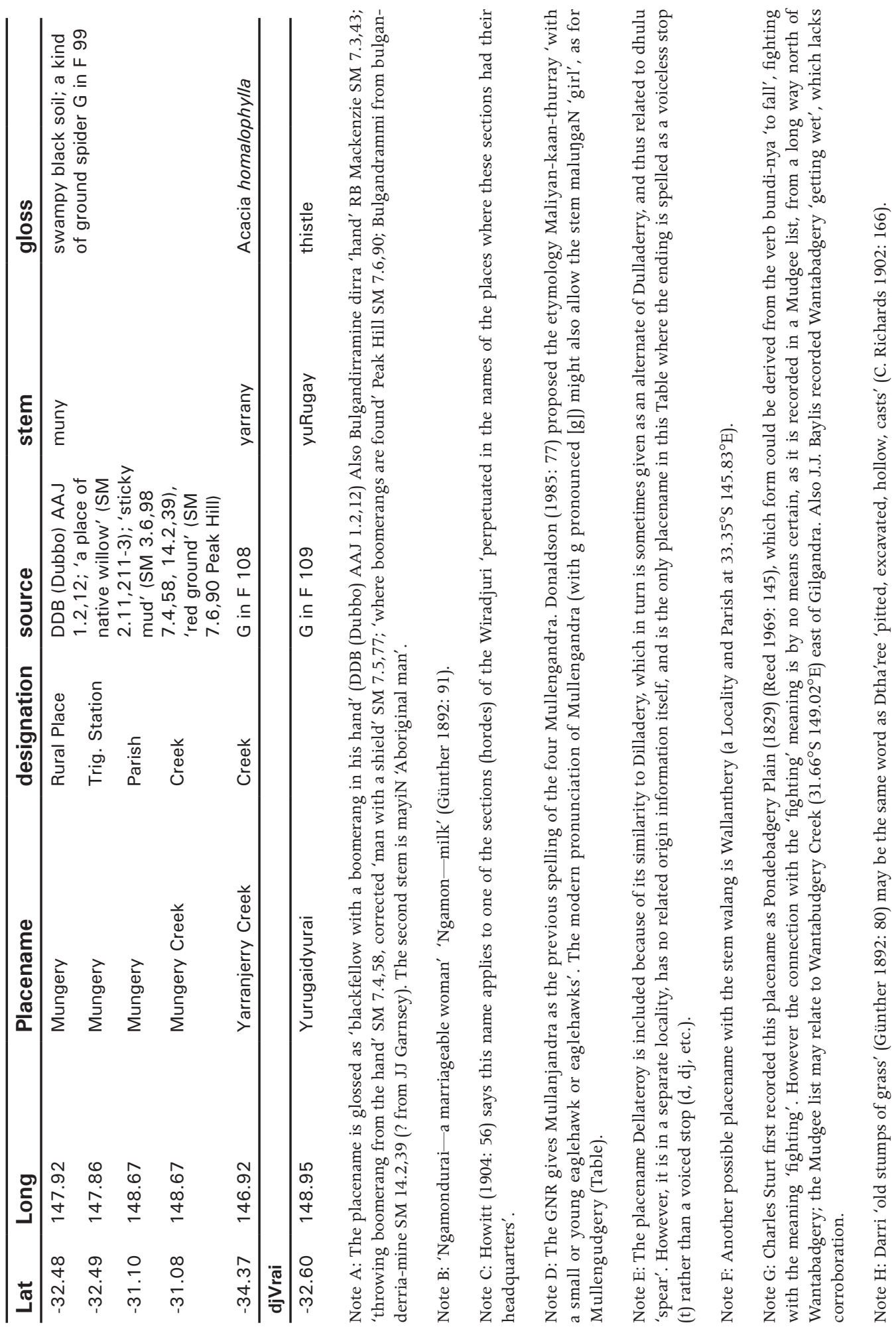


Indigenous and Minority Placenames

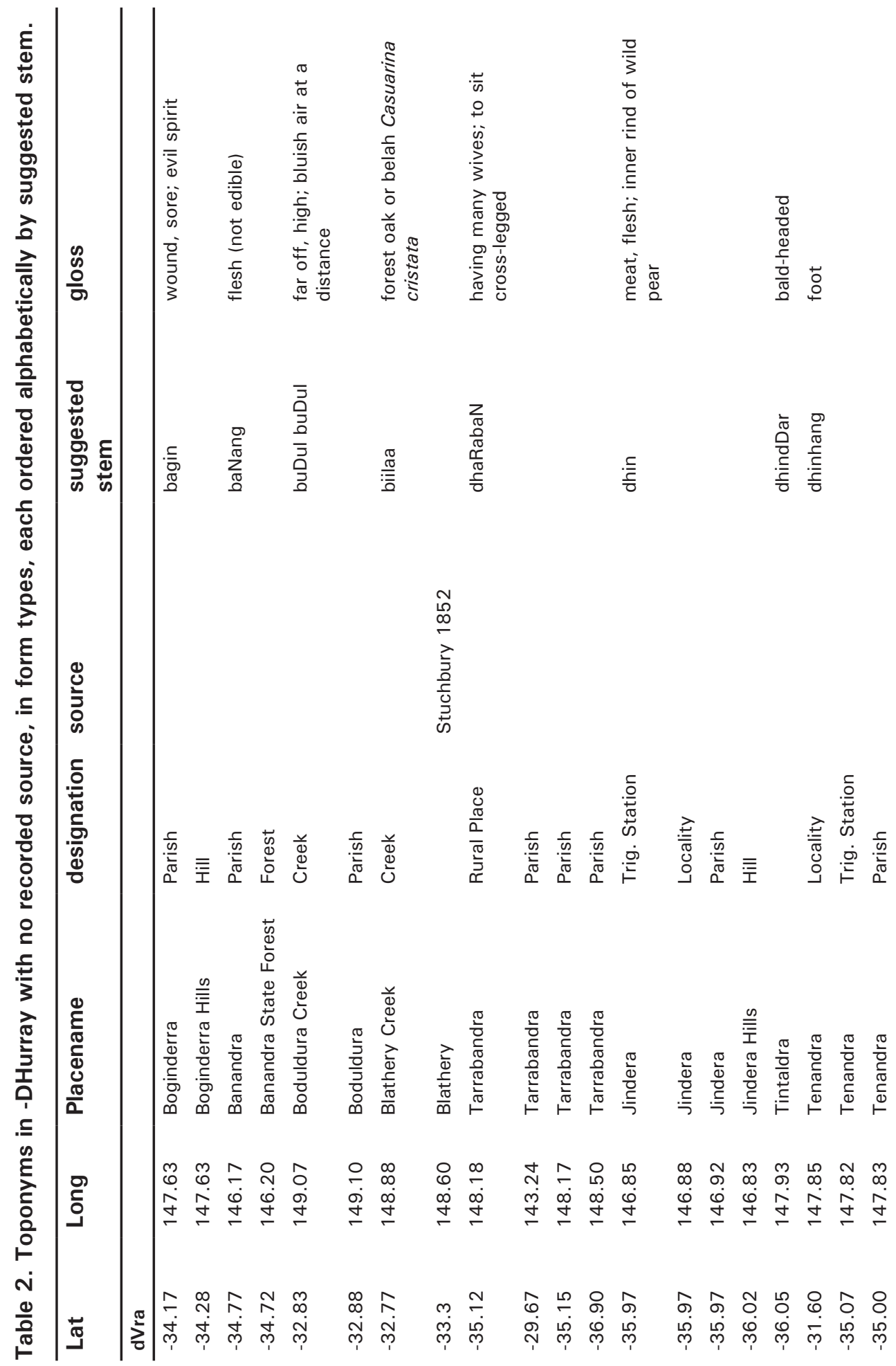



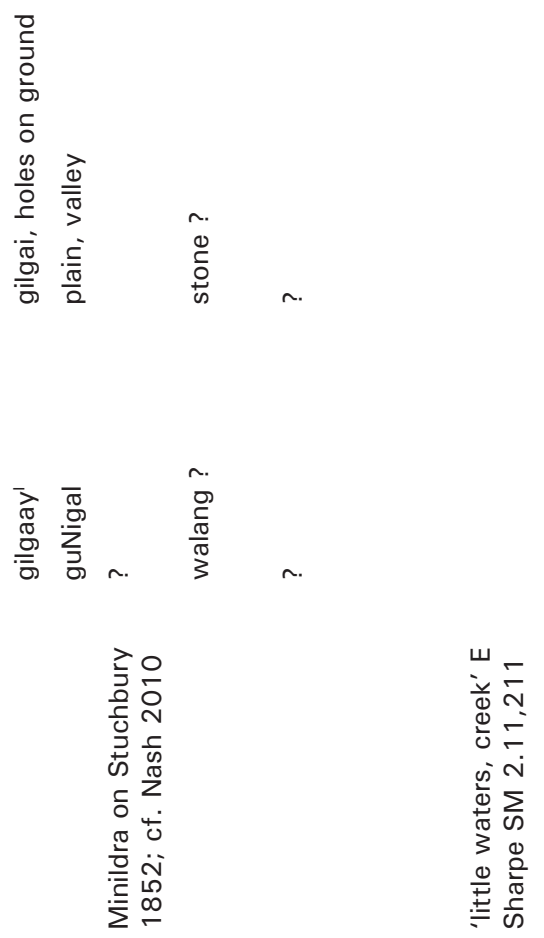

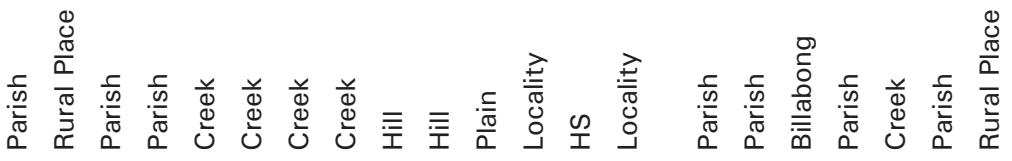

苞

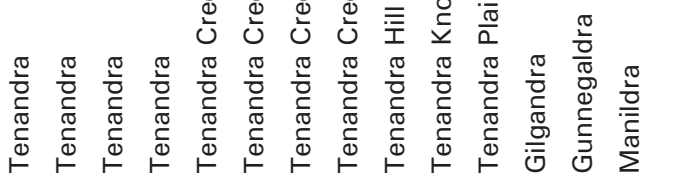

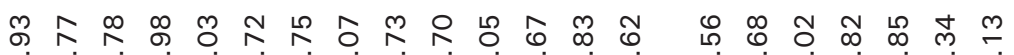

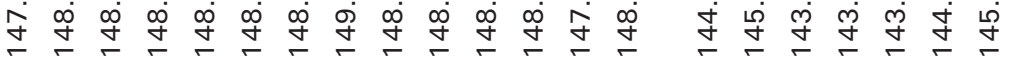

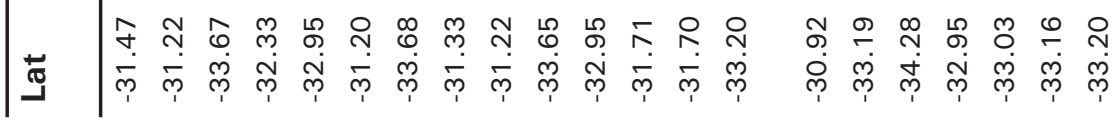


Indigenous and Minority Placenames

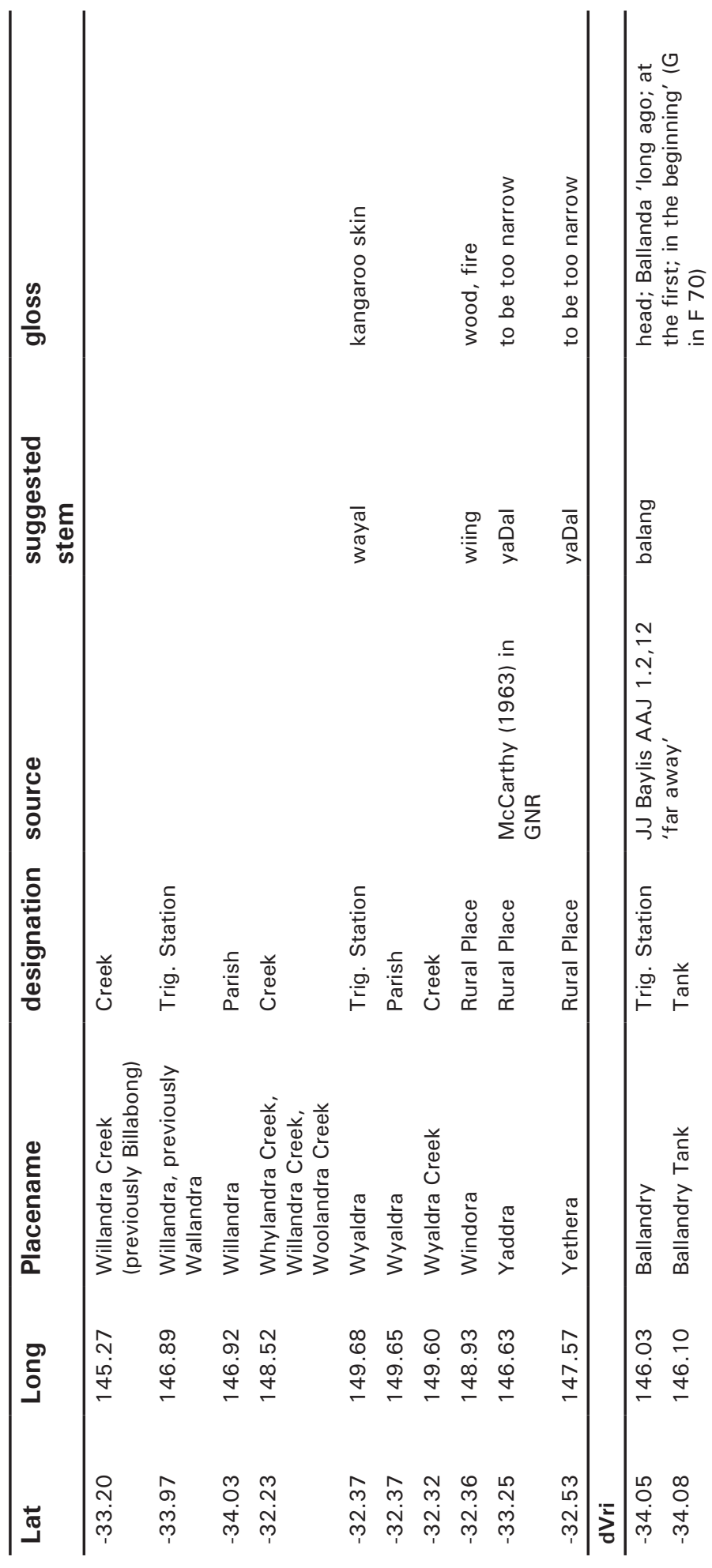




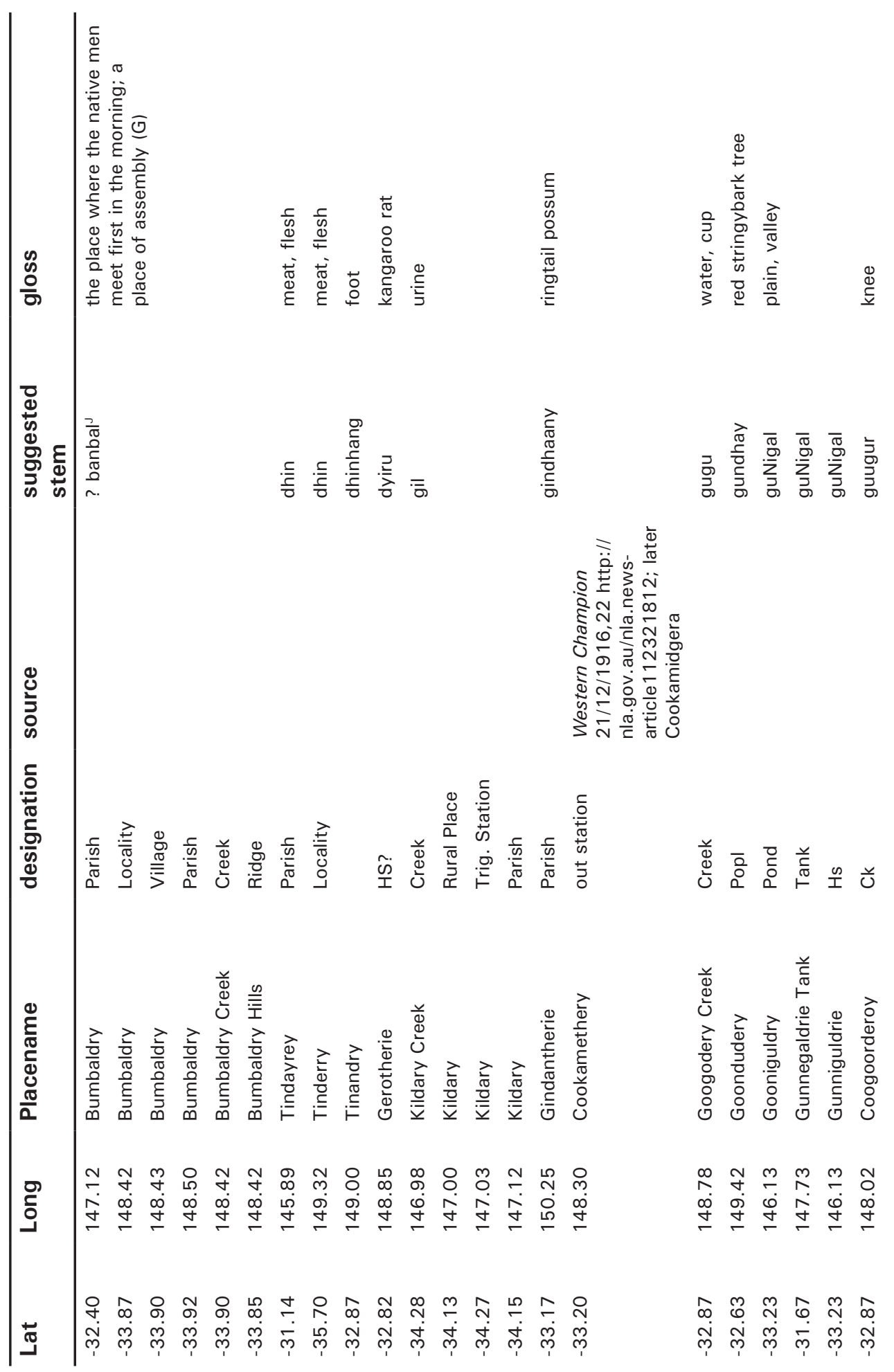




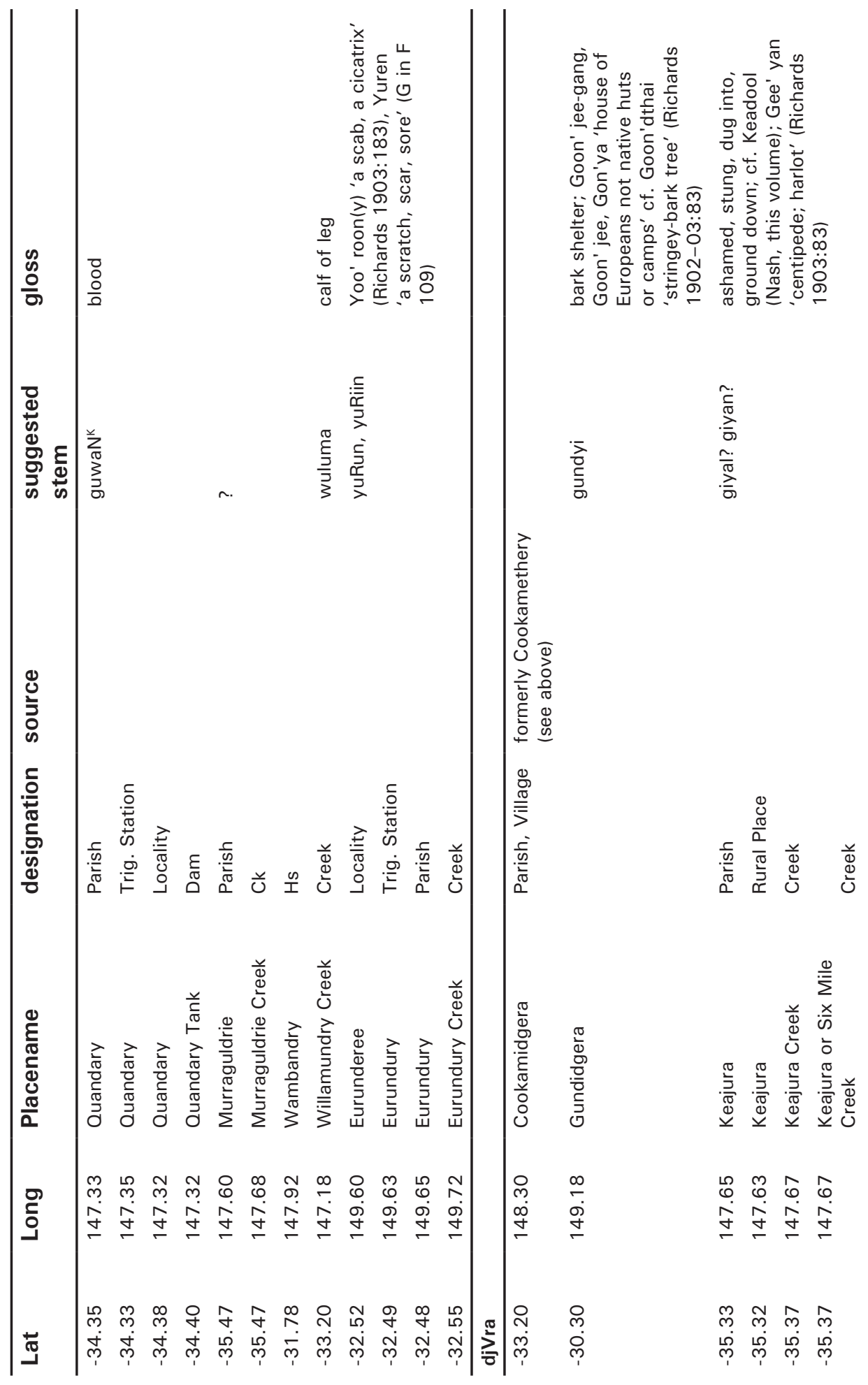


2. Comitative placenames in central NSW

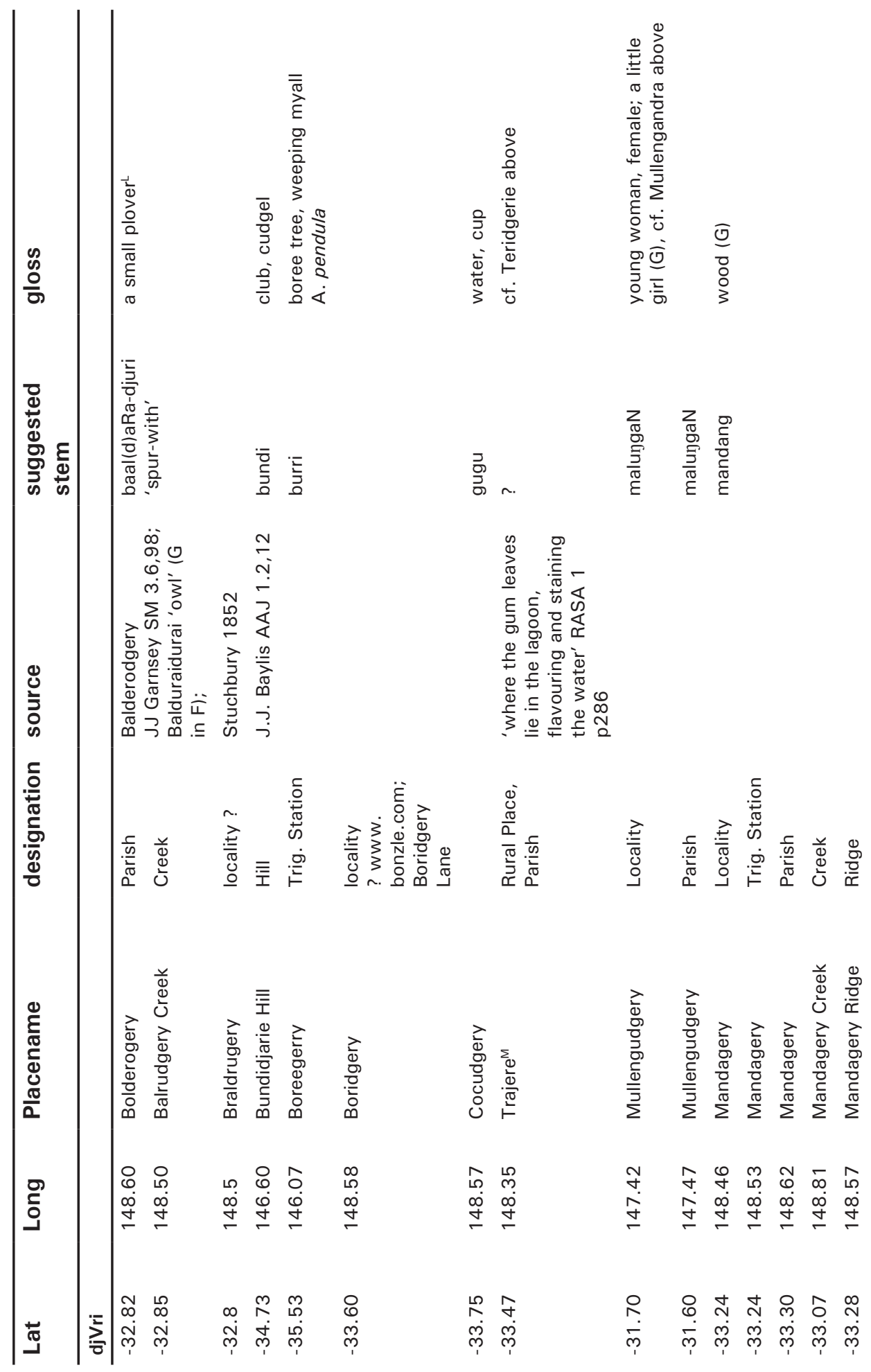




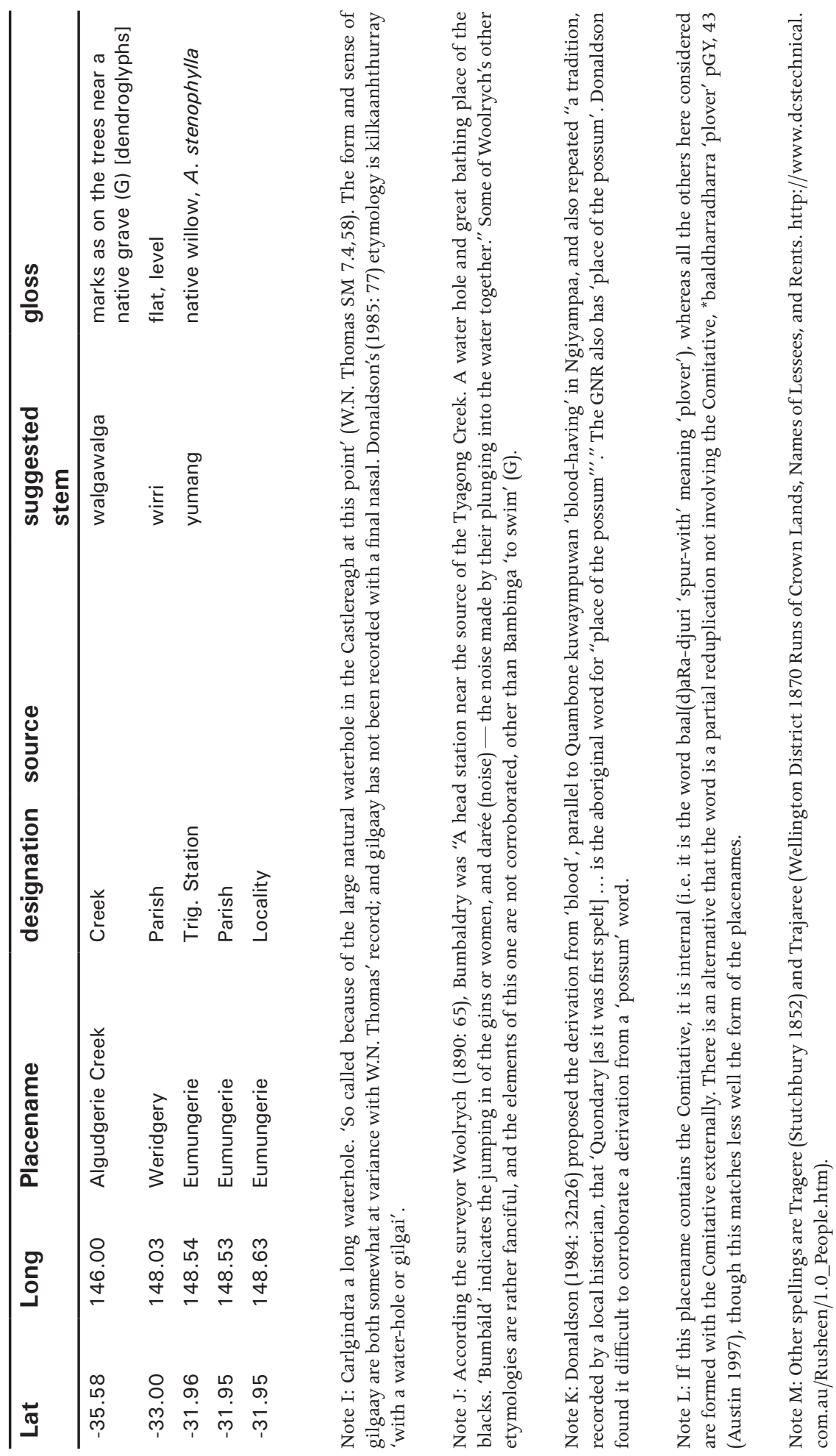


2. Comitative placenames in central NSW

Table 3: Comitative placenames recorded by Günther.

\begin{tabular}{|c|c|c|}
\hline Günther placename & source & comment \\
\hline Dawindurai & $\begin{array}{l}\text { 'present sheep station' } \\
\text { (Günther } 1840 \mathrm{MS}, \mathrm{p} \text {. } \\
341=97 \text { ) }\end{array}$ & $\begin{array}{l}\text { Douwingerie 'rocks from which } \\
\text { stone tomahawks were made' } \\
\text { (Wellington district, Science of } \\
\text { Man 7.6(1904),89), from dhawiny } \\
\text { 'axe, stone axe' }\end{array}$ \\
\hline Gunnandurai & $\begin{array}{l}\text { 'a constellation of } \\
\text { three stars seen in the } \\
\text { eastern horizon soon } \\
\text { after sunset' G } 1839 \\
\text { MS6 p. } 73\end{array}$ & $\begin{array}{l}\text { root possibly meaning 'yellow', cf. } \\
\text { gunanggunang 'yellow ochre' }\end{array}$ \\
\hline $\begin{array}{l}\text { Murrumbìrraíduraí } \\
\text { Murrumbugirrí }\end{array}$ & $\begin{array}{l}\text { Günther } 1840 \text { MS p. } \\
343\end{array}$ & cf. Murrumbidgerie in Table 1 \\
\hline Yurugaidyurai & $\begin{array}{l}\text { 'name of the mountain } \\
\text { near my home' } \\
\text { (Günther 1892:109) }\end{array}$ & $\begin{array}{l}\text { Yurugai 'thistle' (Günther } \\
\text { 1892:109) }\end{array}$ \\
\hline
\end{tabular}

\section{References}

Abbreviations in tables 1 and 2:

AAJ = Australasian Anthropological Journal (continued by SM)

G in F = Günther in Fraser: Günther 1892

GNR $=$ Geographical Names Board 2011

$\mathrm{R}=$ Richards (1902-03)

RASA $=$ Royal Anthropological Society of Australia

$\mathrm{SM}=$ Science of man and journal of the Royal Anthropological Society of Australasia

Some further details on sources are given at http://www.anu.edu.au/linguistics/ nash/aust/wira/.

Austin, P. 1997, 'Proto central New South Wales phonology', in Boundary Rider: Essays in Honour of Geoffrey O'Grady, Darrell Tryon and Michael Walsh (eds), Pacific Linguistics C-136, Canberra: 21-49.

Baylis, J. J. 1900, Vocabulary of the Wiradjuri language, AIATSIS PMS 3887.

- 1927, The Waradgery language (also spelled Wiradjuri or Wiradhuri), [J. Baylis], Euroa, [Vic.]. Reel CY 2549; Original held at Mitchell Library at MLAb 159/1. 
Indigenous and Minority Placenames

Bowern, C. 2011, Centroid Coordinates for Australian Languages v2.0. Google Earth . $\mathrm{kmz}$ file, available from http://pamanyungan.sites.yale.edu/language-resources (accessed 7 July 2013).

Cain, M. J. 1923. 'Coonabarabran in the 'Sixties', Royal Australian Historical Society - Journal and Proceedings 8, supplement: 370-373. Reproduced in RASA 2004, roll 2, PDF, pp. 23-26.

Donaldson, T. 1980, 'Ngiyambaa, the Language of the Wangaaybuwan', Cambridge Studies in Linguistics 29, Cambridge University Press, Cambridge.

- 1984, 'What's in a name? An etymological view of land, language and social identification from central western New South Wales', Aboriginal History 8(1/2): $21-44$.

- 1985, 'Hearing the first Australians', in Seeing the First Australians, Ian Donaldson and Tamsin Donaldson (eds), George Allen \& Unwin, Sydney, London, Boston: 76-91.

Geographical Names Board 2011, Geographical Names Register (GNR) of NSW, Land and Property Information, New South Wales, http://www.gnb.nsw. gov.au/name_search (accessed 6 May 2012).

Geoscience Australia 2008, Gazetteer of Australia 2008 Release, searchable at http://www.ga.gov.au/map/names/ (accessed 6 May 2012). See also Gazetteer of Australia 2010 Release.

Grant, S. and J. Rudder 2010, A New Wiradjuri Dictionary, Restoration House, $\mathrm{O}^{\prime}$ Connor, ACT.

Günther, Rev. J. W. (Jakob Wilhelm) 1838-40, Vocabulary of the Native/ Aboriginal Dialect ... spoken in the Wellington District \&c \&c \&c; Unpublished manuscripts: 1838 MS Wirradurri, 1839 MS Wirradhurri (microfilm at AIATSIS Library), 1840 MS Wirradhurrei.

Günther, J.W. 1892, 'Grammar and vocabulary of the Aboriginal dialect called the Wirradhuri', Appendix D, in An Australian language as spoken by the Awabakal 're-arranged, condensed and edited with an appendix by John Fraser', Charles Potter, Govt. Printer, Sydney: 56-120. http://en.wikisource. org/wiki/Page:An_Australian_language_as_spoken_by_the_Awabakal. djvu/376 (accessed 8 July 2013).

Hale, H. 1846, 'The languages of Australia [including 'Wiradurei']', in Ethnology and Philology, Volume 6 of Narrative of the U.S. Exploring Expedition during the years 1838, 1839, 1840, 1841, 1842, under the command of 
Charles Wilkes, U.S.N, C. Sherman, Philadelphia: 479-531. http://www.sil. si.edu/digitalcollections/usexex/navigation/ScientificText/usexex19_07b. cfm?start=502 (accessed 8 July 2013).

Howitt, A.W. 1904, The Native Tribes of South-East Australia, Macmillan and Company, London.

Koch, H. 2009, 'The methodology of reconstructing Indigenous placenames: Australian Capital Territory and south-eastern New South Wales', in Aboriginal Placenames: Naming and Re-naming the Australian Landscape, edited by Harold Koch and Luise Hercus (eds), Aboriginal History Monograph 19, ANU E Press and Aboriginal History Incorporated, Canberra: 115-171. http://epress.anu.edu.au?p=17331/ (accessed 6 May 2012).

McCarthy, F. D. 1963, New South Wales Aboriginal Place Names and Euphonious Words, with their Meanings, Australian Museum, Sydney.

Nash, D. 1974, 'The comitative affix in Wiradhuri', ANU Linguistics (Arts) term paper, copy held at AIAS Library, pMs 3688.

- 2010, 'A further note on Manildra', Placenames Australia: Newsletter of the Australian National Placenames Survey, December 2010: 6-7. http://www. anps.org.au/documents/Dec_2010.pdf (accessed 8 July 2013).

Reed, A.W. 1969, Place-names of New South Wales: Their Origins and Meanings, Reed, Halstead Press, Sydney.

Richards, C. 1902-03, 'Wirra'athooree. Wirrai'yarrai'. Wirrach'aree'. Wirra'jerree' (or, Aboriginal dialects)', Science of Man 5(5): 81-83 (G); 5(6): 98-102 (G,B); 5(7): 114-119 (B,G,W); 5(8): 133-138 (M,N,Ny); 5(9): 146-149 (Ng); 5(10): 165-168 (Ng,J,Dth); 5(11): 180-183 (Dth,Y); 5(12): 198-201 (Y,Gw,I,E).

Royal Anthropological Society of Australia (RASA) 2004, Royal Anthropological Society of Australia manuscripts dated 1900. 'anthropological society of aus roll 1', PDF file. CD-ROM, Geographic Names Board of NSW.

[Stutchbury, S.] 1852, [Geological map of area south of Dubbo to Lachlan River], State Library of New South Wales, Call No. Ca 85/35. http://acms.sl.nsw. gov.au/album/albumView.aspx $?$ itemID $=977102 \&$ acmsid $=0 \quad$ (accessed 8 July 2013).

Woolrych, F.B.W. 1890, 'Native names of some of the runs \&c. in the Lachlan District', Journal and Proceedings of the Royal Society of New South Wales 24: 63-70. http://www.biodiversitylibrary.org/item/131299 (accessed 8 July 2013). 
This text taken from Indigenous and Minority Placenames: Australian and International Perspectives, Edited by Ian D. Clark, Luise Hercus and Laura Kostanski, published 2014 by ANU Press, The Australian National University, Canberra, Australia. 